\title{
Approaches to the Assessment and Development of Digital Competence of Personnel of Innovative Industrial Enterprises
}

\author{
A. K. Petrova ${ }^{1}$, N. V. Lashmanova ${ }^{2}$, M. A. Kosukhina ${ }^{3}$ \\ St. Petersburg Electrotechnical University "LETI" \\ St. Petersburg, Russia \\ 19ak72p@yandex.ru, ${ }^{2}$ natalasha2007@mail.ru, ${ }^{3}$ masha.kossukhina@mail.ru
}

\begin{abstract}
European Parliament, computer literacy is recognized as one of the $8 \mathrm{key}$ competencies of the 21 st century. The article discusses the evolution of the concept of digital competence, its key components, characteristics, levels, types, approaches to assessment. The mutual influence of the development of digital competence of personnel and the evolution of the personnel function of the organization, as well as their influence on the criteria for the effectiveness of digital transformations of an innovative industrial enterprise, is analyzed. Approaches to improving methods for evaluating and developing digital competency are proposed.
\end{abstract}

Keywords - digital competence of personnel; criteria for the effectiveness of digital transformations; innovative industrial enterprises; assessment methods; evolution of personnel functions

\section{THE CONCEPT OF DIGITAL COMPETENCE}

According to the recommendations of the European Parliament, in addition to communication skills on native and foreign languages, mathematical literacy and basic competencies in science and technology, learning skills, social and civic competencies, innovativeness and entrepreneurship, awareness and the ability to express oneself in the cultural sphere, computer literacy is recognized as one of the 8 key competencies of the 21 st century. [1]

In the era of Industry 4.0, employees of innovative industrial enterprises have to take on new responsibilities, play new roles, strengthening existing and creating new knowledge and skills. The concept of digital competence of personnel has appeared, which includes the skills of ethical, responsible and safe interaction with innovative technologies and the information itself.

For the first time in 1997, Paul Gilster, an American writer and journalist, introduced the concept of digital competency. "Digital competency is the ability to understand and use information provided in a wide variety of formats and a wide range of sources using computers". [2]

According to [1], digital competency involves the confident and critical use of information for work, leisure and communication, based on the basic skills in the field of information and communication technologies: using computers for searching, evaluating, storing, producing, presenting and exchanging information, as well as communicating and participating in collaborative communities over the Internet. [1]

A. Ferrari (2012) proposed the following definition: "Digital competency is the set of knowledge, skills, relationships, abilities, strategies and awareness that are required for using information and communication technologies and digital media to perform tasks, solve problems, communicate, information management, cooperation, the creation and exchange of content, the accumulation of knowledge effectively, efficiently, appropriately, critically, creatively". [3]

In Russia, one of the significant developments in digital competence was the book with the results of a study by G.Soldatova "Digital Competency of Adolescents and Parents", 2013. She considers digital competence as the individual's ability, based on continuous mastery of knowledge, skills, motivation, responsibility, to effectively, critically and safely choose and apply information and communication technologies in different areas of life (working with content, communication, the technosphere, consumption), as well as its readiness for such activities; it is not only the sum of knowledge and skills, but also the attitude towards effective activity and personal attitude to it, based on a sense of responsibility. [4]

The Regional Public Center for Internet Technologies (ROCIT) annually evaluates the digital literacy index of the population of the Russian Federation. In the framework of this project, digital literacy is understood as a set of knowledge and skills that are necessary for the safe and efficient use of digital technologies and Internet resources. Digital literacy includes three elements - digital consumption, digital competencies and digital security, each of which also consists of a number of elements. Digital consumption means the ability to use Internet services for work and life, digital competencies are skills for the efficient use of technologies, and digital security is the basis of Internet security. [5]

\section{SEVEN CHARACHTERISTICS OF DIGITAL COMPETENCE ARE STANDING OUT [3]:}

1. Information management: the ability to identify, find, access, receive, store and organize information; 
2. Cooperation: participation in online communities, social networks, constructive interaction;

3. Communication and exchange of information through online tools, maintaining account confidentiality, security and network etiquette;

4. Content and knowledge creation: integration and processing of existing knowledge, creation of new knowledge;

5. Ethics and responsibility, knowledge and compliance with the legal framework;

6. Assessment and solution of problems: determination of digital needs, solution of problems using digital tools, assessment of the result;

7. Technical operations: using technology and media, performing tasks using digital tools [3]

The components of modern digital competence can be characterized as the following [3]:

1. Computer literacy is defined as "an understanding of the characteristics of a computer, capabilities and applications, as well as the ability to realize this knowledge." Simonson, Maurer, Montag-Torardi \& Whitaker (1987)

2. Internet literacy refers to the skillful use of the Internet.

3. Media literacy - the ability to analyze and critically evaluate media messages and a media environment consisting of television, radio, newspapers, films and the Internet, as well as create media products.

4. Information literacy is defined as the ability to extract information, access it, understand it and use it.

5. Visual or imaginative literacy, or the ability to view, understand and use a large number of materials involving videos, icons and other imaginative means. (Eshet-Alkalai, 2004).

6. Operational skills - knowledge required when using digital tools [3]

Additional skills could be added:

7. The skill of relationships and communications in the digital community.

8. The level of responsibility when conducting activities in the digital space;

9. Motives and motivating intentions of digital activity and digital communications;

10. The speed and flexibility of making and mastering new digital solutions.

Following classification features to determine the types of digital competency could be consided:

1. By type of activity in the digital sphere (areas of life, benefits): professional activities, family tasks, leisure, personal development, creativity, communications, shopping, working with information, participation in public life, technical tasks;

2. By profession: digital competence of a programmer, accountant, teacher, etc.;

3. For the purposes of working with information: consumption of information to solve problems, creating new information.

4. By level of proficiency: basic, advanced, expert levels;

5. By age: digital competence of a teenager, senior citizen or middle-aged person;

6. According to the level of interaction with society: individual, characterizing the individual, and public digital competency, characterizing the society or organization;

7. By the nature of motivating intentions: destructive, neutral, positive digital competence;

8. Internal, aimed at solving personal problems and external, aimed at solving social problems, digital competence could be distinguished;

These features may intersect with the others, forming a kind of network segmentation of digital competence.

When considering digital competence in the context of an industrial enterprise during the period of digital transformation, according to [7], the skills necessary for innovative transformations are following: digital security, mobile technologies, business change management, Big Data analytics, cloud computing, Internet of things, business networks, integration product / service, databases and memory, entrepreneurship, social media, artificial intelligence, new interfaces, blockchain.

According to the professional standard [8], the generalized functions of the human resources management system are the following: documentation support for work with personnel, activities to of personnel, staffing activities, personnel development activities, organization and remuneration of staff, operational personnel management of the company's unit, strategic personnel management of the organization.

By integrating the skills necessary for digital transformation with the functions with the tasks of HR department, the components of the digital competence of employees of an enterprise in the period of innovative changes could be classify and considered both in relation to employees of the HR service and other employees of the enterprise as a whole, as follows:

1. Staffing - skills of employee recruitment software;

2. Employee development - skills of training and career path software;

3. Skills of accounting software for mobile workers and remote work;

4. Remuneration of labor - understanding of the principles of work of payroll and payroll software;

5. Performance appraisal - skills of performance appraisal software; 
6. Skills of social communications within the organization: ownership of applications and software of internal corporate media.

7. Skills of professional software for one's workplace;

8. Skills of creating documents, presentations, spreadsheets, the use of other features of infographics;

9. Digital flexibility: the speed of adoption and development of new digital solutions;

10. Skills of big data analytics;

11. Skills in digital and cyber physical security;

12. Skills of strategic management software (for executives).

It is obvious that during the period of digital transformations, the level of digital competence of both HR employees and employees of the enterprise as a whole is a determining criterion, or metric, for assessing the level of evolution of personnel processes in an industrial enterprise. And since the "human resource" is the most significant resource of the enterprise during the transformation period, the level of development of personnel processes can be a leading indicator for assessing the effectiveness of digital transformations of an innovative industrial enterprise, and the digital competence of personnel makes a significant, if not decisive, contribution to this assessment.

To assess the level of digital competence of personnel, at the moment it is customary at enterprises to use the method of information questioning of employees regarding their ownership of software, applications, etc., by levels "I know, apply, create" using a point scale. [9]

It is proposed that the following principles could be introduced into the digital competency assessment process:

1. To proceed when compiling individual profiles from the integrated profile of the digital competence of the enterprise;

2. To identify the positions and digital competencies that are key to transformation;

3. To base while preparing the digital competency profile on the core competency profile of the position;

4. To consider the results as integrated with other HR metrics of digital transformation: involvement, level of responsibility for security, etc.

5. To carry out an assessment of digital competency on an ongoing basis.

\section{DIGITAL COMPETENCE ASSESSMENT ALGORITHM:}

1. Identification of key elements of digital competence critical for digital transformation;

2. Compilation of an ideal integrated profile of digital competence of the entire enterprise;

3. Determining the level of digital competence of the enterprise, corresponding to the states of "readiness", "not ready", "conditional readiness" of the enterprise for digital transformations;

4. Identification of critical for digital transformation job positions of innovative industrial enterprises;

5. Compilation of ideal digital competency profiles of key positions based on their core competency profile;

6. Compilation of a questionnaire to assess the digital competency of key positions

7. Conducting a test survey on the focus group;

8. Making adjustments to the questionnaire, if necessary;

9. Survey, comparison with the reference profiles of key positions, and the ideal profile of the digital competence of the entire enterprise;

10. Integration of the assessment of the level of digital competence with the assessment of other HR metrics of the enterprise during the period of transformation;

11. Assessment of enterprise' readiness degree for digital transformation, based on the assessment;

12. Identification of steps to adjust and increase the level of digital competence, if necessary, or to begin the implementation of digital transformation;

13. Implementation of the intended steps;

14. Periodic monitoring of digital competency level;

15. Evaluation of digital transformation effectiveness.

The listed principles and algorithms undoubtedly as well determines the personnel competency model of a modern industrial enterprise.

In addition, as part of this work, a new approach is proposed to assess the effectiveness of the digital transformation of an innovative enterprise, as a set of BSC positions, taking into account the main directions of the National Index of Digital Economy Development [10]. For a comprehensive assessment of the effectiveness of the digital transformation of an innovative enterprise, it is proposed to use the model developed by the authors (1):

$$
\begin{array}{r}
K P I_{\text {int }}=\sum_{i=1}^{l} w_{i} \sum_{k=1}^{n} w_{k} K P I_{k}\left(1-p_{k}\right) \\
\left\{\begin{array}{l}
\sum_{k=1}^{n} w_{k}=1 \\
\sum_{k=1}^{n} p_{k}=1 \\
\sum_{i=1}^{l} w_{i}=1
\end{array}\right.
\end{array}
$$

where $\mathrm{w}_{\mathrm{k}}$ is the weight of the corresponding highlighted key performance indicator for the $\mathrm{i}$-th position, $\mathrm{w}_{\mathrm{i}}$ is the weight of the integrated key performance indicator for the i-th position, $\mathrm{p}_{\mathrm{k}}$ is the average total risk for the corresponding highlighted key performance indicator of the $\mathrm{i}$-th position, $\mathrm{n}$ is the number of identified key performance indicators for the i-th position, 1 is the number of positions. [11, 12] 
To rank the weight of the corresponding selected key performance indicator by the $\mathrm{i}$-th position $\left(\mathrm{w}_{\mathrm{k}}\right)$ and the weight of the integrated $\mathrm{KPI}_{\mathrm{i}}\left(\mathrm{w}_{\mathrm{i}}\right)$, a hierarchical model was developed using the T. Saati scale of relative importance according to the Fechner psychophysical law of indirect estimation. The developed hierarchical model, depending on the ranking of the interests of participants in innovative activities, the maturity level of the business processes of the innovative industrial enterprise, allows us to calculate the value of the weights $\left(\mathrm{w}_{\mathrm{k}}\right.$, $\mathrm{w}_{\mathrm{i}}$ ) of key performance indicators for the i-th position of the BSC $\left(\mathrm{KPI}_{\mathrm{k}}\right)$ and integrated key performance indicators for $\left(\mathrm{KPI}_{\mathrm{i}}\right)$ by $\mathrm{i}$-th position of the BSC, respectively.

Thus, the article discusses the concept of digital competence, its levels, characteristics, types. New components of digital competence and criteria for its classification are proposed. The key role of digital competence in the effectiveness of digital transformations, the principles and algorithm for assessing digital competence, as well as an approach to assessing the performance indicators of digital transformations of an innovative industrial enterprise are shown.

\section{REFERENCES}

[1] Recommendation of the European Parliament and of the Council of December 18, 2006 on key competences for lifelong learning. Official Journal of the European Union, L394 / 310.

[2] Gilster P. Digital Literacy. N.Y.: Wiley Computer Publishing, 1997, 152 p.

[3] A. Ferrari. Digital Competence in Practice: An Analysis ofFrameworks, European Commission Joint Research Center Institute for Prospective Technological Studies, 2012. Available at: http: //jiscdesignstudio.pbworks .com / w / file / fetch / 55823162 / FinalCSReport_PDFPARAWEB.pdf. (accessed 08/20/2019)
[4] Soldatova G.U., Nestik T.A., Rasskazova E.I., Zotova E.Yu. Digital competence of adolescents and parents. The results of an all-Russian study. Moscow: Internet Development Fund, 2013 b. 143 p. (in Russian).

[5] Regional Public Center for Internet Technologies (ROCIT) available at: http: //xn--80aaefw2ahcfbneslds6a8jyb.xn--p1ai/ (accessed 08/20/2019) (in Russian).

[6] What is digital capability? Digitalcapability, UK, 2018. Available at: https://digitalcapability.jisc.ac.uk/what-is-digitalcapability (accessed on 08/20/2019)

[7] Skills for Digital Transformation. Research Report 2017. The study was conducted by experts at the Munich Institute of Technology (MTI) and SAP, $10 \mathrm{p}$.

[8] "Consultant Plus", Legal base order of the Ministry of Labor of Russia dated 06.10.2015 No. 691n "On approval of the professional standard" Specialist in personnel management "(registered with the Ministry of Justice of Russia on October 19, 2015 No. 39362) (in Russian).

[9] Dovgal V.A. Assessment of ICT competence of a public service specialist. Vestnik Majkopskogo gosudarstvennogo tekhnologicheskogo universiteta [Bulletin of Maykop State Technological University]. 2010. No1. Available at: https://cyberleninka.ru/article/n/otsenka-iktkompetentnosti-spetsialista-gosudarstvennoy-sluzhby (accessed: 10/09/2019) (in Russian).

[10] National Index of Digital Economy Development: Pilot Implementation, Moscow, RosAtom State Corporation. 2019. 92 p. (in Russian).

[11] I.A. Brusakova, V.A. Dreschinsky, V.I. Fomin, M.A. Kosukhina, V.L Gorokhov: Teoreticheskaya innovatika uchebnik $i$ praktikum dlya bakalavriata $i$ magistratury [Theoretical Innovation textbook and workshop for undergraduate and graduate programs]. Moscow, 2018, 333 p. (in Russian)

[12] Brusakova I.A., Fomin V.I., Kosukhina M.A., Panin S.N. Issledovanie tendencij razvitiya informacionnogo menedzhmenta $v$ sovremennyh usloviyah: monografiya [Study of information management development trends in modern conditions], St. Petersburg, Publishing House of the St. Petersburg University of Management and Economics, 2014. 138 p. (in Russian) 